\title{
Fuel pump promos: continued
}

Jennifer $M$ indell spotted a new venue for cigarette advertising in the UK in 1997-fuel pump handles at petrol (gas) stations. ${ }^{1}$ In A pril of this year, I came across the same marketing technique in Somerset, Pennsylvania, USA, at a Turkey $\mathrm{H}$ ill $\mathrm{M}$ init $\mathrm{M}$ arket, where this convenience store and an Exxon gas station are operated jointly.

On the day I visited the $M$ init $M$ arket, all of the cigarette ads appearing on the fuel pump handles promoted a special sale of Camel, Winston, and Salem cigarettes (RJ Reynolds) for $\$ 25.48$ a carton (fig 1). Similar ads appeared inside the store on a self service cigarette display rack. Some of the fuel pump handles advertised food or beverage products. A sales clerk informed me that the ads on the fuel pumps rotated among several different brands of foods, beverages, and cigarettes. She showed me a list of the products involved in the rotation, which included another cigarette brand sold by RJ Reynolds (D oral), as well as $M$ arlboro and Basic cigarettes (Philip M orris), and GPC and Viceroy cigarettes (Brown and Williamson).

The sales clerk told me that decisions about which products were to be featured in these promotions came from the Turkey $\mathrm{Hill}$ headquarters in L ancaster, Pennsylvania. But because the cigarette ads on the fuel pump handles include the brands' logos and the Surgeon $\mathrm{G}$ eneral's warning, one must assume that the cigarette companies authorised (or were directly involved in) these ad placements. No doubt they recognise the value of fuel pump ads, as explained by a British marketing company that sells space on the nozzles:

"Our advertisers are communicating their message on a one-to-one basis directly to their end-customer, in an undisturbed environment for an average of two to three minutes at a time when the customer has little alternative but to hold the message in their hand and gaze at it."

On its website (www.turkeyhill.com), Turkey $\mathrm{H}$ ill has a calendar of events supported by the

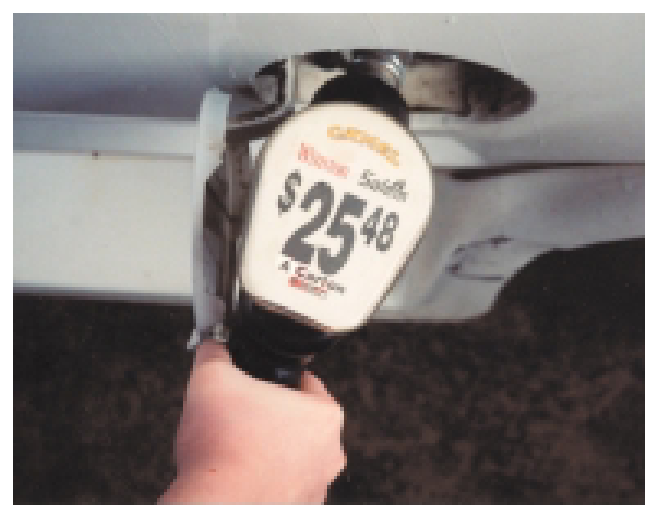

Figure 1 Cigarette ad on a fuel pump handle.

company. The calendar for April 2001 included an Easter egg run benefiting a paediatric rehabilitation centre, a walk for multiple sclerosis, a race/walk for breast cancer research, and a "loving \& caring annual walkfor-life" in support of "life-affirming organizations across the county". Given the "life-affirming" efforts by Philip Morris, RJ Reynolds, and Brown \& Williamson to stamp out world hunger, domestic violence, poverty, homelessness, and many other social ills, ${ }^{2-4}$ opportunities for partnership between Big Tobacco and Turkey $\mathrm{Hill}$ would seem to be endless.

$\mathrm{H}$ enry F ord $\mathrm{H}$ ealth System

RONALD M DAVIS

0 ne Ford Place, $5 \mathrm{C}$

Detroit, M ichigan 48202-3450,

USA

rdavis1@ hfhs.org

1 M indell J. Fuel pump promos. Tobacco Control 1997;6:35960.

2 Philip Morris Companies Inc. Philanthropy. URL: www. philipmorris.com/philanthropy/philanthropy_main.asp (accessed 16 A pril 2001)

3 RJ Reynolds Tobacco Company. Inside RJ R: responsibility to the community. URL: www.rjrt.com/C O/pages/C OH owWeT hink community.asp (accessed 16 A pril 2001)

4 Brown and Williamson Tobacco. Community involvement and Corporate contributions. URL: www.brownandwilliamson.com/ Index_sub2.cfm?ID =12 (accessed 16 April 2001) 


\section{Putting a positive image on death and disease: tobacco industry slogans around the world}

Cambodia

"Towards a better future" (555/BAT)

"T he honour of the nation"

"Smoking is for honour and integrity" $\mathrm{G}$ reg $\mathrm{H}$ allen, W H O

\section{Bangladesh}

"T he brighter future" (555/BAT)

"A taste apart" (Player's G oldL eaf/BAT)

"Follow the excitement"

"Follow the world adventure"

"Join the adventure"

"Go for the challenge"

"C elebrating the spirit of adventure"

"Be gold, art \& literature ... one $\&$ only ... heart $\&$ soul . . . now $\&$ forever . . . taste $\&$ flavour . . . taste $\&$ enjoy . . . body $\&$ soul . . . here $\&$ now . . . pick $\&$ choose . . before $\&$ after . . .

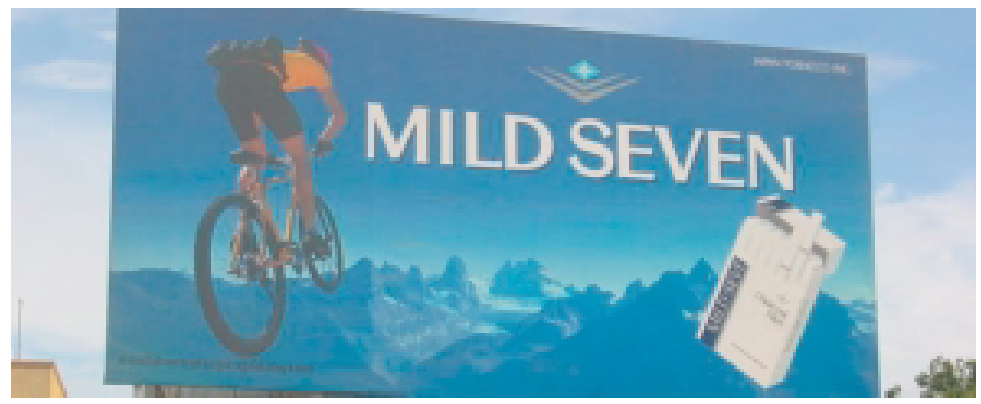

Figure 1 M ild Seven in Cambodia.

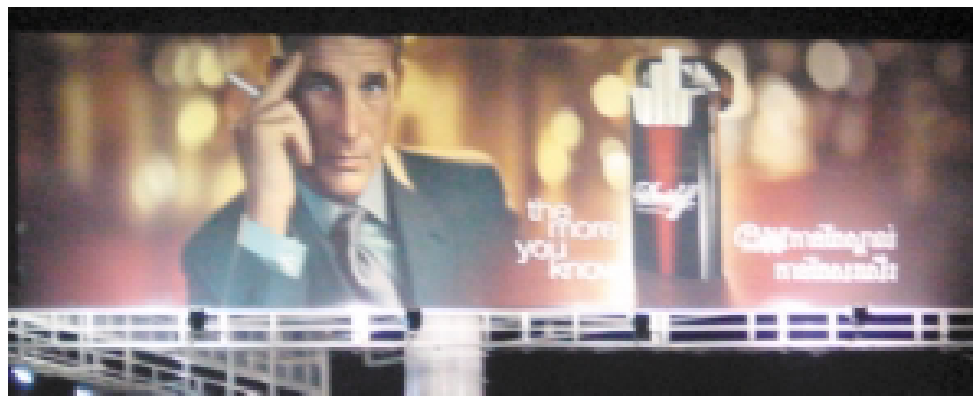

Figure 2 "The more you know". D avidoff advertises above a fun park in Cambodia. The billboard carries no health warning.

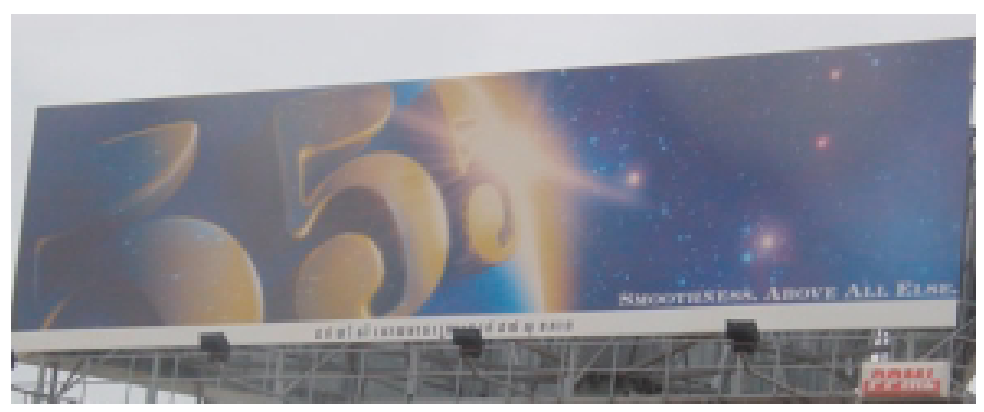

Figure 3 "Smoothness above all else" 555 in Cambodia. light $\&$ white . . . live $\&$ electric . . live $\&$ explosive ... hours $\&$ hours (for a rock concert) ... twist $\&$ shout . . . relax \& enjoy . . . up \& down . . . answer $\&$ win" (Benson and Hedges/ BAT ).

Debra Efroymson, PATH Canada

D emocratic $R$ epublic of $C$ ongo

"You know, cool at any time" (Ambassade/BAT)

"Together we will succeed" (Tumbaco legère/BAT )

"G ood spirit, good taste" (Tumbaco legère/BAT )

"T he faithful friend" (O kapi/TABACONGO)

"T he American dream" (D allas/Philip M orris)

Wazi M ulum, Blue Cross

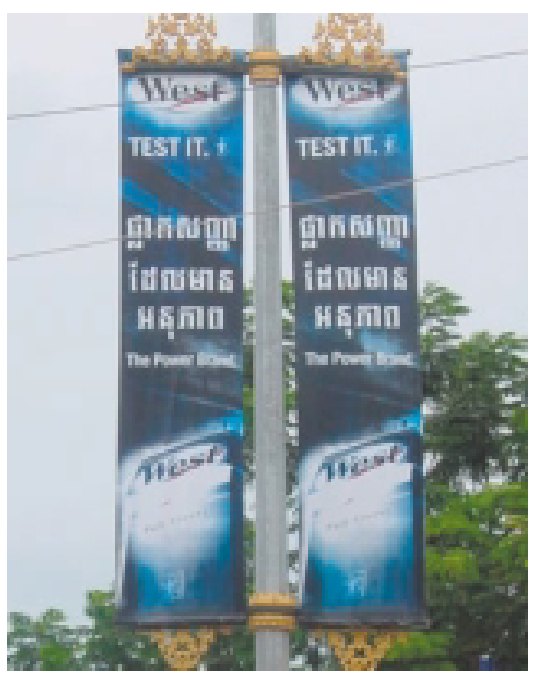

Figure 4 "Test it" and "The power brand". B anners for West line the streets in Cambodia. The banner positions were used for the Cambodian flag.

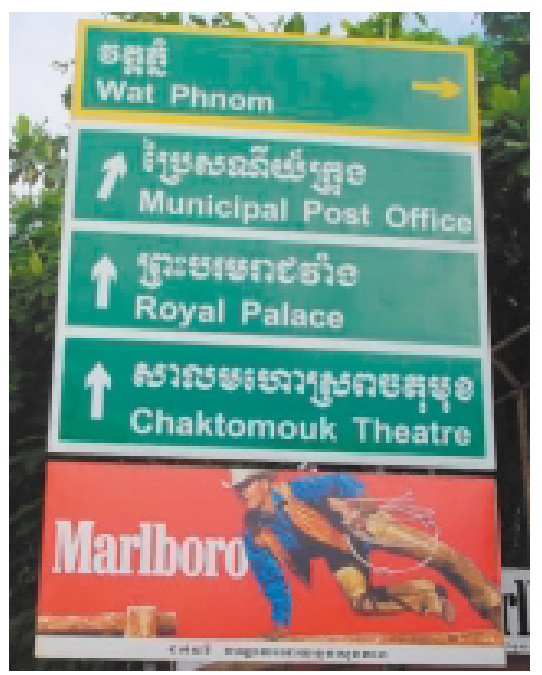

Figure $5 \mathrm{M}$ arlboro street sign in Cambodia. 
India

"Live life K ingsize" (Four square)

from the magazine Colours

Indonesia

"Taste the freedom" ( $K$ ansas/Philip M orris)

Japan

"Perfect days" (L ark/Philip M orris)

Senegal

"T he real American taste" (L\&M /Philip M orris)

"U SA uthentic" (H ouston)

"Perfection all the time" (Excellence)
U ganda

"True taste, true spirit" (Sportsman)

"Smooth all the way" (E mbassy)

"T he winner's choice" (Supermatch)

"T he test of success" (Rex)

D unstant K iwanuka

Serbia \& M ontenegro

"For people who want more" (Walter Wolf)

"F reedom has no limits" (Ronhil/R ovinj, C roatia)

"H ow to spend a million?" (Pall M all/BAT)

"T hink about it" (Pall M all/BAT)

A ndjelka D zeletovic, Institute of Public $\mathrm{H}$ ealth of Serbia

\section{AD WAT CH}

\section{Worshipping at the Alpine altar: promoting tobacco in a world without advertising}

\begin{abstract}
"Glisten. The party to go with your glamourpuss dress." "G listen. M usic to go with your rockstar hair." "Glisten. Cocktails to go with your spanking ring." ("M inimum age 18. Photo ID required. Tobacco \& alcohol products for sale."1) Three highly stylised advertisements, one for each byline, and each featuring a young woman on the dancefloor flaunting dress, hair and ring respectively, had been splashed in expensive full colour across the street music press and on the Wavesnet website (www.wavesnet.net) for weeks (fig 1). On the night of T hursday 6 September at least some glamourpusses believed the hype at the high profile nightclub Home, located in Sydney's CBD waterfront entertainment district. A report on the sparkling event in a moment, but first, a bit of context.
\end{abstract}

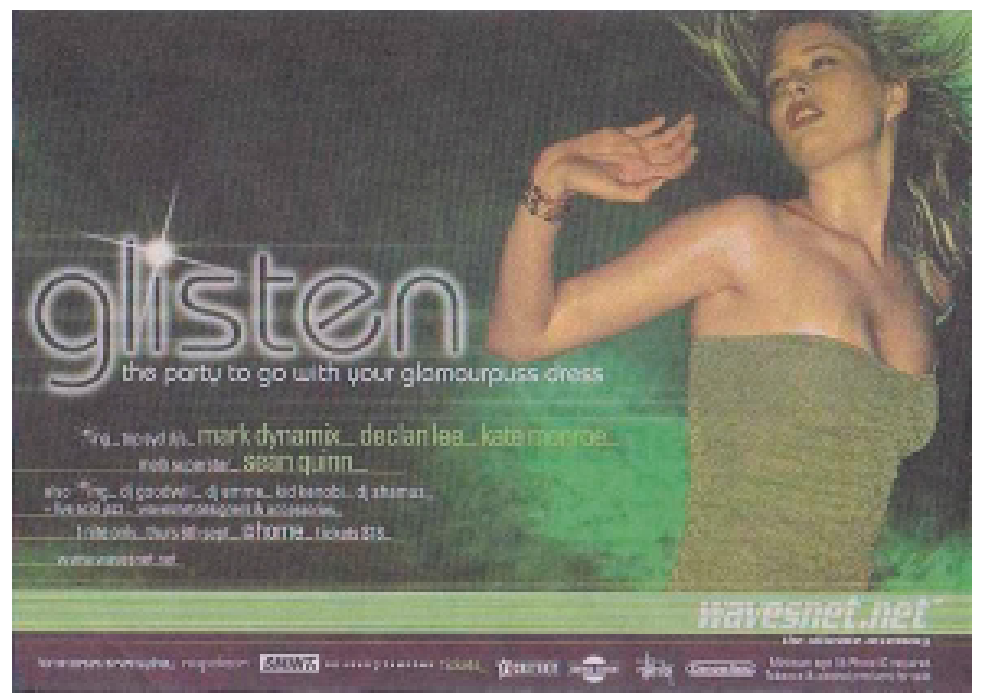

Figure 1 A dvertisement for "G listen", a party sponsored by Wavesnet.
Australia passed its Tobacco Advertising Prohibition Act in 1992. Its stated objective was to "improve public health" by limiting messages and images that could persuade Australians to start or continue to use tobacco. ${ }^{2}$ It defines "advertisements" broadly, as " . . . any writing, still or moving picture, sign, symbol or other visual image, or any audible message, or any combination of two or more of those things, that gives publicity to, or otherwise promotes or is intended to promote" among other things, purchase or use of tobacco, or tobacco trade marks and designs. ${ }^{2}$ The Act prohibits the publication of any such advertisements, with some defined exceptions (including point of sale, which is now being phased out in most states). ${ }^{2}$ Publication is defined so broadly that, generally speaking, under the Act any activity that brought a tobacco design or brand to the attention of a section of the public, gave it publicity, promoted it or intended to promote it, could be considered a breach.

Big tobacco is nothing if not creative. A number of authors have documented a new trend in "getting around" such stringent advertising restrictions: event promotion via third parties. Action on Smoking and $\mathrm{H}$ ealth U K has highlighted the use of this strategy by British American Tobacco in Europe via the www.citygobo.com website, ${ }^{34}$ and Tobacco Control has recently documented the similar use of Wavesnet in Australia. ${ }^{5}$ Wavesnet was established in October 2000 by M ojo (the advertising agency managing Philip M orris's Alpine account in Australia), and the two share directors and are owned by the same company. Wavesnet promotes and sells "must have" items for young women online, and collects the demographic details and consumer preferences of users in return for information and 
invitations to events. ${ }^{56}$ An incentive to "sign up" to the database is provided by a $10 \%$ discount in the "online shop". ${ }^{1}$

The first round of Wavesnet events was a series of fashion awards at which roving "cigarette girls" sold Alpine for less than recommended retail and cigarettes could readily be taken from displays without payment. ${ }^{56}$ $\mathrm{N}$ egative publicity followed, and Phillip M orris reportedly first claimed that their involvement was transparent and thus benign, and then, in the face of continued condemnation, promised that it would not happen again. ${ }^{7}$ So when the green and glamorous advertisements for Glisten, a party sponsored by Wavesnet, emerged, Australian tobacco control advocates were keen to see whether they would stick to their promises. To find out, I bought a ticket and joined the fray.

\section{VIP playground}

The attitude started on arrival. Glisten aimed to provide its patrons with an "A list" identity from the front door onwards. Portable barriers divided the entranceway into sections, and provided (literally) red carpet treatment for "VIP Wavesnet members" only. Given that anyone who claims to be over 18 can become a member online, it's a pretty efficient trip to stardom. There were identification checks on the door, which seemed less focused for the "members"; however, I didn't see any 13 year olds waved through, and the crowd certainly seemed familiar enough with club etiquette. The actual ages of individual ticket holders is probably less important than the fact that the average age was younger that the usual club crowd, with a majority in their late teens or early 20 s.

There is no doubt that the party was bankrolled by someone: the DJs (including out-of-towners) were excellent and a generous design budget had marked G listen as a Wavesnet event. Wavesnet's colours, font, and $\operatorname{logos}^{1}$ were everywhere-green and gold columns lit from the inside displayed Wavesnet action girl silhouettes around the edges of the floor; mirror balls, metallic confetti and metallic body painted go-go dancers reflected the Wavesnet-green lighting design; and the projection screen (a common feature of dance parties) interspersed the "Glisten" and Wavesnet advertising images with live camera feeds of the crowd and the usual abstract computer generated patterns.

Wavesnet acts as an umbrella for cutting edge design and fashion companies, and they got plenty of exposure. In a large side room beauty experts gave makeovers in front of backstage dressing room-style mirrors bordered by bare lightbulbs (using the featured brand of cosmetics). The girls' rest rooms held free tampon samples. On catwalks and stages cute, confident, and incredibly young models "performed" special fashion shows, wearing, carrying, and drawing attention to the Wavesnet range of earrings, hairclips, bags, and jewellery. T hey also displayed the names of the featured designers, who were often in attendance to be applauded at the end of the shows, providing an air of $\mathrm{M}$ ilan-Paris-L ondon authenticity. N ext to the catwalk, sleek laptops could be used to purchase the merchandise, alongside glass cabinets displaying the real thing. A pair of slightly older girls roamed the crowd with clipboards, hot-pink cowboy hats on their big blonde hair, tight "ask me how you could become a rockstar" t shirts revealing their perfect stomachs, collecting the contact details of girls who looked young and funky enough to match the Wavesnet image. And, of course, the DJs played and the party people danced.

\section{The Alpine altar}

By now I am sure that those of you familiar with industry tactics are shouting "show me the tobacco". Cigarettes played a subtle, but special, role in the evening. The regular cigarette vending machine had been put away for the night, one assumes to control the range of tobacco products available. Just inside the front entrance, to one side, near the main drinks bar and the main dance floor, stood a luminous white altar to Alpine. It was a small curved bar, with a white back wall containing an alcove custom built to hold and highlight a block of Alpine cigarette packets, massing the white and silvery green design of the brand. It was lit to provide a soft, otherworldly glow. And most lovely of all, it was tended at all times by a pair of gorgeous, glamorous, ageless women, identical icons, in shiny silver-white bobbed wigs, long sparkling white gowns, and perfect faces. Alpine, it seemed, was my ticket to timeless screen siren status, with a futuristic twist.

I asked one of the visions whether she had anything other than Alpine, and with an understanding smile, she opened a hidden drawer to display a small supply of $\mathrm{M}$ arlboro and $\mathrm{M}$ arlboro Light. All brands were for sale at prices similar to retail and the only way to procure cigarettes was to take the initiative and ask the glittering angels in white-there was no possibility of theft, and nothing as trashy as roving "cigarette girls" or free giveaways. This was not about cheap and nasty adolescent entry to menthol. This was about style. This was about seduction. This was about a brand.

$\mathrm{N}$ aomi Klien, a Canadian journalist and media commentator, has recently taken Sydney by storm with her book "N o L ogo". ${ }^{8}$ It is a must for anyone hoping to combat global marketing and the inexorable march of the transnationals, and a few points are particularly salient here. G one are the days, argues $\mathrm{K}$ lien, when a smart company invested in improving its product and informing its consumers. We are now in a world of branding. M ultinationals like Nike have outsourced the dirty and troublesome business of manufacturing, transforming themselves into marketing companies. Their profit maximisation strategy? To make their identities and logos emblematic of a lifestyle to which we can aspire, so that, irrespective of what benefit the brand actually confers, we embrace it as an "actualisation" of our true selves and institutionalise it at the heart of our culture. No anecdote of Klien's illustrates this more chillingly that the fact that 
the Nike "swoosh" logo has become the most requested design in tattoo parlours all over North America: consumers so thoroughly co-opted that they clamour to brand even their own bodies. ${ }^{8}$

\section{The new market}

$K$ lien also reflects on the newest generation of consumers and the techniques designed to sell to them. M edia savvy, information rich, and postmodern, 21st century kids see through traditional advertisements in a second, and in response, the marketing machine has changed gear. C ompanies now recruit M T V generation staff to leadership positions. T hey commission "Cool H unters" [sic] to ensure that their messages are suitably ironic and ahead of the cutting edge. And, despite the fact that they can advertise freely through the mass media, they pay boutique marketing companies who specialise in "building word of mouth in urban areas and inner cities" - that is, hiring and paying "street crews" and individual youth to talk up new product as part of their everyday lives (new bank accounts on university campuses, new hip-hop releases downtown). The new world of marketing is one-on-one, the campaigns are part of your ordinary conversations, the salesperson is the coolest kid in your class, and you don't know that she is on the payroll. T he marketing has gotten as cynical as its audience, and it is way under their skin.

So how does all of this relate to a dance party on a waterfront in the southern hemisphere? It certainly raises questions regarding strategy and objectives. Since the Sydney party at least two of the sponsors, informed of the Philip M orris connections, have publicly expressed surprise and disappointment, and one has withdrawn from an upcoming M elbourne event. Whatever purpose Wavesnet achieves, it apparently justifies risking the wrath of other businesses. ${ }^{9}$ One hypothesis, that Wavesnet is a means to extend Alpine green beyond the cigarette packet, seems improbable: it's crass, and besides, the two greens clash, and in branding consistency is everything. T he idea that Wavesnet is there to create a database of potential Alpine smokers and their consumer preferences seems more likely, and worth pursuing in light of the Wavesnet website disclaimer: "[By registering] you grant wavesnet. net the right to disclose to third parties your U ser Information, other than credit card details ... . for the purposes of any transmission of the business conducted by wavesnet. net relating to this web site." ${ }^{11}$

If I had been one of the 18 year olds at G listen, I would have seen three types of women working for the promoter, all in matching pairs or threes to heighten the impact. F un, cheeky, energetic girls my own age modelled hairclips and handbags: I doubt I would remember what they looked like the next day, the accessories were the star there. Older, white trash rockstars took my demographic details, but I'm pretty sure they were just a bit too cheap for me to want to be them. The high priestesses of the Alpine Altar rose above, and their silvery styling was as clear a brand as any tattoo: glittering, white, and glamorous. They are the ones I'm most likely to talk about in the morning.

What did G listen do? G listen created a world to which most young women in a consumer society would aspire, a world which contains their ideal sounds, looks, venues, people, and technology: in short, a lifestyle. G listen casually placed Alpine, along with many other interesting activities, in that lifestyle. Perhaps Alpine was only one of many featured products because young Australian women in 2001 are too smart to accept blatant tobacco sponsorship of their public space. Perhaps it was a shield against the Tobacco Advertising Prohibition Act, allowing the argument that the altar was not promotion, but design in keeping with a larger event. Perhaps it was to provide Alpine with vicarious legitimacy from the presence of other products, heightened when Alpine was made just a little more desirable than the whole range of desirable things. Did G listen attract the coolest young women, imitated by others, who are so valuable to youth marketing? Was the all important wordof-mouth created? Did Glisten add to a database which will be available to Alpine's marketing team? D id it contribute to the creation of a brand so conceptually powerful that girls would be prepared to damage their bodies to internalise the qualities it stands for? We need to ask these questions, and I'm sure Wavesnet's directors know the answers. Because if other transnational marketing companies are inside the minds of the next generation of consumers, you can bet that Phillip $M$ orris is there too.

ST ACY CARTER

D epartment of Public $\mathrm{H}$ ealth and $\mathrm{C}$ ommunity M edicine,

The U niversity of Sydney,

$\mathrm{N}$ ew South Wales 2006,

A ustralia

carters@ health.usyd.edu.au

Thanks to Simon Chapman, Jonathan Liberman and Todd $\mathrm{H}$ arper for advice during writing.

1 Wavesnet website (online). URL: www. wavesnet.net Accessed 7 September 2001.

2 Commonwealth of Australia. Tobacco Advertising Prohibition Act 1992 (online).URL : http://www.austlii.edu.au/au/ legis/cth/consol_act/tapa1992314/index.html (accessed 7 September 2001)

3 ASH UK. Citygobo2 website (online). URL: http:// www.citygobo2.com/ (accessed 10 September 2001).

4 Citygobo website (online). URL: www.citygobo.com (accessed 10 September 2001).

$5 \mathrm{H}$ arper $\mathrm{T}$. M arketing life after advertising bans. Tobacco Control 2001;10:196-7.

$6 \mathrm{H}$ eraldSun. Teenage fun bankrolled by tobacco giant online). 11 D ec 2000.U RL: http://news.com.au/common/ story page/0,4057,1506226\%255E 421,00.html (accessed 7 September 2001)

7 Chapman S. Tobacco advertising promotion and packaging in Australia (online) 2000. URL: http:// cessed 7 September 2001).

8 K lein N. N o logo. L ondon: Flamingo/H arperC ollins, 2001.

$9 \mathrm{M}$ oor K. Tobacco giant a secret sponsor. H erald Sun (M elbourne) 2001; Sept 10:10. URL: http:// www.heraldsun.news.com.au/printpage

$0,5481,2812550,00 . \mathrm{htm}$ 